\title{
The Future for Public Sector Procurement Law in the Post-Brexit Period
}

\author{
Miltiades C. Elliotis*
}

After the UK's momentous vote to leave the EU, in June 2016, a significant number of public sector officials, began wondering about the future of public procurement in the UK and in the EU, during the post-Brexit period. The consequences of Brexit in this area, as in many others, are in fact difficult to predict; they depend essentially on future political decisions, particularly on the UK's relationship with the EU. What is clear is that the current procurement regulations will remain in the UK as they are, during the negotiating period, which will probably last until the end of 2019. How will procurement be regulated after that? Certainly, there will be no change in procurement regulations in the EU. What about the corresponding UK regulations? One realistic possibility is that the UK will negotiate a trade agreement with the EU that covers public procurement. Therefore, this could allow the UK to apply the EU procurement regime exactly as it is now. This means that the UK will leave the EU but still be a party to the European Economic Area (EEA) Agreement. Consequently, there will be no change in the procurement regulations in the UK since in essence the EEA applies the same rules on public procurement as the EU does. A second option is for the UK to negotiate another type of trade arrangement with the EU which would certainly include public procurement provisions and it is possible, that these would be the same as those under EU/EEA rules. A third possibility is that the UK will not conclude any specific trade agreement with the EU but that UK trade will be based simply on commitments under the WTO agreements such as the Government Procurement Agreement (GPA) and the General Agreement on Tariffs and Trades (GATT) that currently apply for the UK as part of the EU. A final option is for the UK not to commit to any trade agreements that constrain its strategy for regulating public procurement. This means that with this option it will be difficult to predict the final form of UK public procurement law. All these scenarios are discussed in the present work.

\section{Introduction}

The United Kingdom has formally started the process of leaving the European Union. This has immersed the UK government and EU Institutions in a two-year period of negotiations to disentangle the UK from the EU law by the end of March 2019 and to devise a new legal framework for UK-EU trade afterwards.

DOI: 10.21552/epppl/2018/2/4

* Miltiades C. Elliotis PhD, M.Sc., Postgraduate Dipl., Civil Engineering, Occupational Psych., Math., Ministry of Interior, European Funds Unit, Republic of Cyprus, Dep. of Math. and Statistics, University of Cyprus, P.O. Box 24908, 1305 Nicosia, Cyprus. E-mail address: <melliotis@moi.gov.cy>, Tel.: +357 22409912; Fax: +357 22409948 .
The UK will thereafter be adjusting its trading arrangements with the rest of the world. In this context, public procurement regulation is broadly seen as an area where a UK procurement law, which does not depend on the EU law, would be able to turn to a lighter-touch and more commercially-oriented.

There are indications that the UK would simultaneously attempt to create a particularly close relationship with the US, although recent changes in US international trade policy may pose some questions on that trade strategy. Overall, then, Brexit has created a scenario where UK public procurement law and policy may be significantly altered. The extent to which this is a real possibility crucially depends on the framework for the future trade relationship between the UK and the EU. 
Whereas "EU-derived law" will not restrict the UK's freedom to regulate public procurement, the conclusion of a closely-knit EU-UK trade agreement covering procurement could thus well result in the country's continued full compliance with EU rules. Nonetheless, this is not necessarily a guaranteed scenario and, barring specific requirements in future free trade agreements between the UK and the EU or third countries, including the US, the World Trade Organization GPA seems to be the only regulatory constraint with which the future UK public procurement reform needs to conform.

Many analysts ${ }^{1}$ believe that the position of the UK under the GPA is far from clear. Furthermore, they posit that the UK will face a GPA accession process and GPA members may interpret Brexit as an opportunity to obtain new concessions from the EU and the UK, which could be both in terms of scope of coverage or regulatory conformity. Further, given the current trend of creating GPA plus procurement chapters in free trade agreements, such as the USKorea FTA, the GPA regulatory baseline will gain even more importance as a benchmark for any future reform of public procurement regulation in the UK, even beyond the strict scope of coverage of the GPA.

Other experts ${ }^{2}$ insist on the possibility of an agreement with the EU based on the GPA which could mean reduced coverage for the UK procurement regime in the areas of utilities, defence and concessions, although also reduced opportunities for UK suppliers abroad in those markets. It would also provide an opportunity for the UK to use more flexible award procedures, more akin to the EU's utilities model than the public sector model, and for a less burdensome system of remedies. However, at this point it would be useful to discuss the purpose of the existing EU-based procurement law.

Procurement was regulated in the EU to foster domestic and European goals, in particular to promote value for money and prevent corruption, but this was done mainly by administrative guidance rather than by legal rules. Bodies of law, enforceable by bidders, were created in all EU Member States only by the regulations that were adopted to give effect to the EU procurement rules, which required this legal approach. Therefore, the "UK public procurement law" has always been for the most part "EU procurement law as applied in the UK". The purpose of this EUbased law is to open up UK markets to bidders from other Member States, although in practice the EU rules are also seen as a useful way to secure national goals such as value for money.

It is thus not surprising that since the referendum result of 23 June 2016 there has been considerable discussion of the possible consequences of Brexit for the UK law of public/utilities procurement. Will this whole body of law disappear along with the EU membership? If no, will this take the UK back to the 1970's and 1980's when public purchases were largely free from the thread of litigation? Or might the current regulations be replaced by different laws to govern contract award procedures? The objective of the present contribution is to give answers to these questions.

The rest of the text is organised as follows: in Section II we will present the current UK procurement regulation. In Section III the scenario that the UK becomes a member of the EEA Agreement ("NorwayStyle" model) will be investigated. Section IV presents and discusses the possibility that the UK will leave the EU but become a party of the "bespoke agreements", which now invariably include EU public procurement provisions. In Section V the GPA option will be analysed and in Section VI the "freedom option" period will be discussed. Finally, in Section VII a possible transition period will be presented and our conclusions will be summarised in Section VIII.

\section{Current UK Procurement Regulations}

Since February 2014 when the EU legislature adopted the three most recent significant measures in this field, the EU public procurement regime has principally consisted of the following very well known and important directives: Directive 2014/24/EU $\mathrm{EU}^{3}$ on procurement in the public sector; Directive 2014/25/EU on procurement by entities operating in the utilities

$1 \quad$ P Telles and A Sánchez-Graells, 'Examining Brexit through the GPA's lens: What next for public procurement reform?' (2017) 47(1) Public Contract Law Journal, 1-33.

2 S Arrowsmith, 'The implications of Brexit for the law on public and utilities procurement' (2017) The CPD Standards Office, CPD Provider: 60043.

3 Directive 2014/24/EU of 26.2.14 on public procurement and repealing Directive 2004/18/EC (OJEU No. L 94/65 of 28.3.14).

4 Directive 2014/25/EU of 26.2.14 on procurement by entities operating in the water, energy, transport and postal services sectors and repealing Directive 2004/17/EC (OJEU No. 94/243 of 28.3.14) 
sectors; Directive 2014/23/EU ${ }^{5}$ on the award of concession contracts; Directive 2009/81/EC ${ }^{6}$ on defense and security procurement; and Remedies Directives 89/665/EEC ${ }^{7}$ (public sector) and 92/13/EEC ${ }^{8}$ (utilities sectors) as both amended by Directive 2007/66/EC . These directives supplement the general principles of EU law applied under the Treaty on the Functioning of the EU ("TFEU"), particularly the fundamental freedoms: the free movement of goods, the freedom to provide services and the right of establishment in any Member State (Figure 1).

The EU public procurement directives are variously implemented into $\mathrm{UK}^{10}$ law by the Public Contracts Regulations $2015^{11}$, the Utilities Contracts Regulations $2016^{12}$, the Concession Contracts Regulations $2016^{13}$ and the Defense and Security Public Contracts Regulations $2011^{14}$ (Figure 1). This large body of procurement law, i.e. "the EU public procurement regime", forms a substantial legislative achievement, a detailed analysis of which is beyond the scope of this work. Suffice it to say that, whilst there are aspects of the regime which arguably represent an unwelcome extension of EU law, it undoubtedly contains much to commend it. Indeed, the UK was enthusiastic about its adoption and has implemented all recent directives ahead of deadlines.

Although there still exists the possibility for aggrieved tenderers to lodge a formal complaint with the European Commission, since the amendment to the remedies regime under Directive 2007/66/EC (notably imposing a mandatory standstill period in respect of procurement awards and an automatic stay on the award of a contract once a claim is commenced), this is now generally unnecessary, as most actions can be satisfactorily brought before the national courts. Since UK economic operators are significant providers of services (and goods) throughout the EU, the UK would benefit from continued

5 Directive 2014/23/EU of 26.2.14 on the award of concession contracts (OJEU No. L 94/1 of 28.3.14).

6 Directive 2009/81/EC of 13.7.09 on the coordination of procedures for the award of certain works contracts, supply contracts and service contracts by contracting authorities or entities in the fields of defense and security, and amending Directives 2004/17/EC and 2004/18/EC (OJEU No. L 216/76 of 20.8.09).

7 Directive 89/665/EEC of 21.12.89 on the coordination of the laws, regulations and administrative provisions relating to the application of review procedures to the award of public supply and public works contracts (OJEU No. L 395/33 of 30.12.89).

8 Directive 92/13/EEC of 25.2 .92 coordinating the laws, regulations and administrative provisions relating to the application of Community rules on the procurement procedures of entities operating rules guaranteeing fair and transparent access to these markets. This is best achieved by maintaining in force the core of the current EU public procurement regime, regardless of the future UK - EU relationship, at least in the short term.

\section{The EEA Membership ("Norway- Style" Model)}

The EEA Agreement provides for close market integration between the EU and the three non-EU members of the European Economic Area: namely, Norway, Iceland and Liechtenstein. Under the EEA Agreement, the rules and remedies of the EU directives on public procurement apply equally in those three EEA territories. Consequently, public authorities in those three countries are obliged to advertise above-threshold public contracts in the EU Official Journal (using one of the EU's official languages) and to comply with the Directives' detailed rules on award procedures. Public contracts that worth less than the Directives' thresholds but still of cross-border interest are subject to non-discrimination and transparency requirements under the EU Treaty.

Applying the EEA Agreement model to the UK post-Brexit procurement law would mean that the EU's Directives on public procurement continue to apply in full to UK contracting authorities and suppliers in the UK and the EU would continue to have full rights of access to each other's markets for public contracts. The EEA Agreement model may ultimately be considered too similar to full EU membership to be acceptable, politically, to the UK Government. The Parliament report therefore floats the possibility of an "EEA-minus" approach, whereby some elements of the EEA model would become ineffective.

in the water, energy, transport and telecommunications sectors (OJEU No.L 76/14 of 23.3.92).

9 Directive 2007/66/EC of 11.12 .07 amending Council Directives 89/665/EEC and 92/13//EEC with regard to improving effectiveness of review procedures concerning the award of public contracts (OJEU No. L335/31 of 20.12.07).

10 At least in England, Wales and Northern Ireland, since separate implementing legislation exists in Scotland.

11 SI 2015 No. 102; in force since 26.2.15.

12 SI 2016 No. 274; in force since 18.4.16

13 SI 2016 No. 273; in force since 18.4.16

14 SI 2011 No. 1848; in force since 21.8.11 


\section{Current UK procurement law}

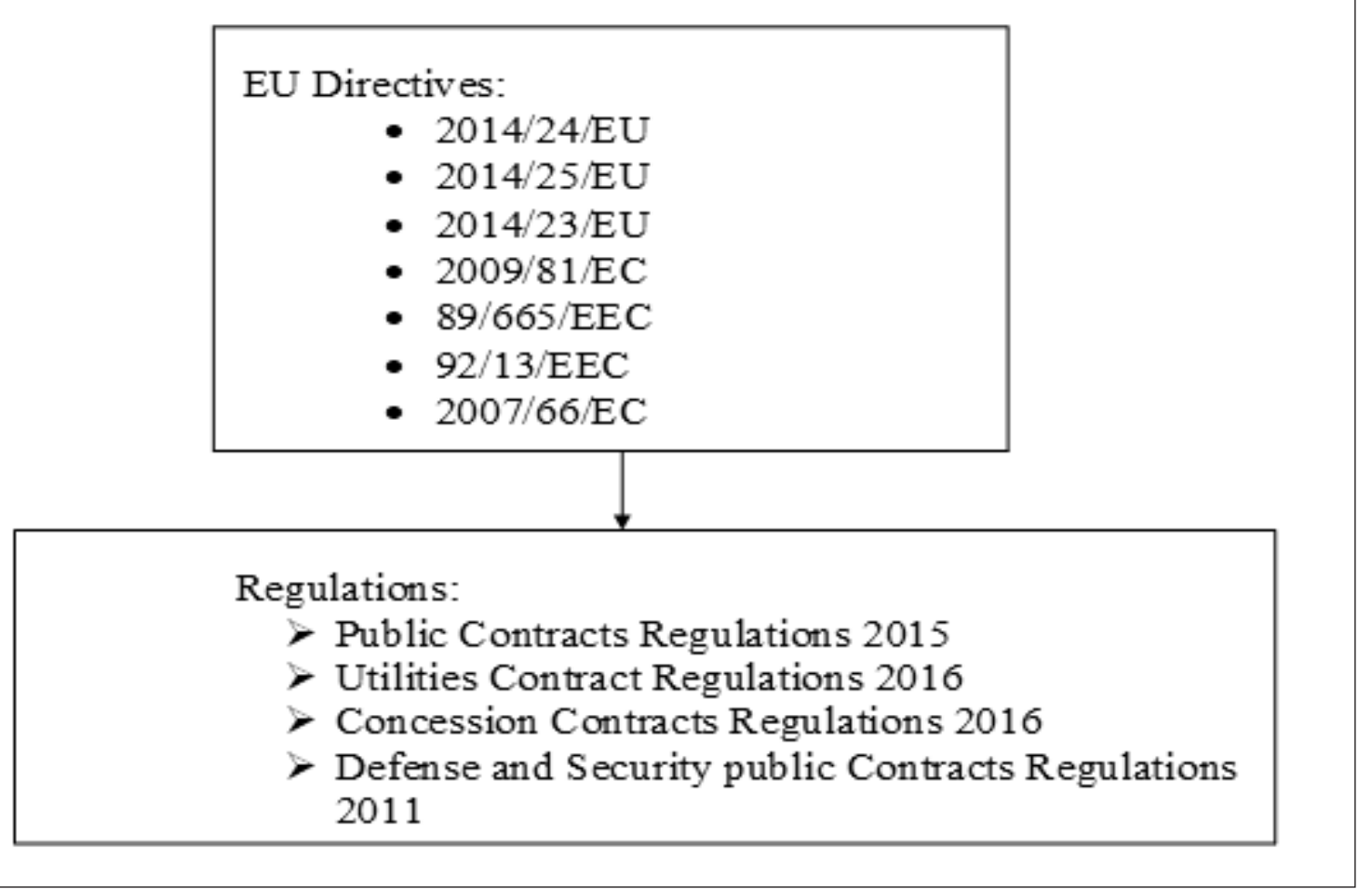

Figure 1

Current UK procurement law.

Source: Author's Compilation.

Thus under this option the UK would essentially carry on applying EU procurement rules and remedies. The current legislation - in England, Wales and Northern Ireland, the Public Contracts Regulations 2015 - would no doubt simply be retained, with minor technical adjustments to reflect the UK's new status. Since all the single market rules apply, UK firms seeking to win contracts in other EEA states will benefit from all other relevant rules just as EU firms do - for example, from not having to pay any tariffs on goods imported for use in public procurement contracts and from rights to set up subsidiary companies in other states of the EEA.

Such a solution, if it is possible at all, will be quite easily reached in terms of the technicalities of negotiations - at least if the UK joins EFTA also - since it is essentially an "off the shelf" solution.

One thing that would change, however, is that the UK would have no vote, and thus a significantly reduced voice, on any future changes to the EU rules - the states of the EEA who are not in the EU can provide de facto input into the legislative process through participation in e.g. the Commission's governmental Advisory Committee on procurement, but influence is clearly limited when there are no voting rights. In the past, the UK has played a positive role in shaping EU procurement rules along commercial rather than bureaucratic lines, most notably, in the author's view, in the provisions on framework agreements and competitive dialogue introduced in 2004. The UK has also had influence in the introduction or adoption of measures of concern to the UK in the 2014 reform process, including the "mutual" exemption and wider use of award procedures involving negotiation. It is true that future amendments will apply only if explicitly adopted by the Joint Committee of the EEA (i.e. both EU and non-EU EEA members), giving non-EU members of the EEA a chance to reject them, but to date all the rules of EU procurement legislation have been adopted for the EEA. 
It is also worth noting that the role of the European Commission in dealing with complaints and the role of the European Court of Justice (ECJ) in hearing cases and giving interpretations would cease for the UK. For Norway, Iceland and Liechtenstein the same functions are carried out by the EFTA Surveillance Authority and EFTA Court, with the EFTA Court in practice following ECJ interpretations. If the UK were to join the EEA it might join EFTA institutions would also take this role for the UK. However, this may be opposed by EFTA states, which are currently small states and may be concerned with a luck of balance with such a large partner - a complication to sorting out the UK's participation in the EEA.

One may now pose the question: Is EEA membership likely? It cannot be ruled out totally. However, a major obstacle is that the EEA single market rules include the rules on free movement which allow migration to the UK from other EEA states - the main issue that influenced many people to vote for Brexit. EEA membership would also require UK significant contributions to the EU budget, something which has been emphasised by many opponents of EU membership. The very fact that EEA membership is effectively "EU-lite" raises questions over whether this option would be in line with the spirit of the referendum outcome. There may also be political objections from other EU members. EEA membership is now perhaps looking less likely that it did in the immediate aftermath of the referendum.

\section{The "Bespoke Option" for the UK Procurement Practices}

With this option the UK has to negotiate another type of trade arrangement with the EU. In the author's view such an arrangement would certainly include public procurement provisions, and it is possible, although not inevitable, that these would be the same as those under EU/EEA rules. The EU has created many bespoke trade agreements that go beyond the EU's general commitments ${ }^{15}$ under World Trade Organization (WTO) rules - for example, providing for lower tariffs for importing goods into the EU than those set in the WTO's General Agreement on Tar-

15 S Fitzgerald, F Roth and B Martens, 'Brexit: Impact on public sector procurement law' (2017) DLA Piper. iffs and Trade (GATT). It is striking that these bespoke agreements now invariably include public procurement provisions. The EU considers its own procurement markets to be open de facto, and is committed to formally opening these markets when partners are willing to reciprocate; and it is insistent on procurement being addressed in any trade agreements that exist in Europe or in other parts of the world.

Thus provisions on broad access to public procurement, using the award procedures of the directives to ensure transparency, are included in the Stabilization and Association agreements concluded between the EU and actual or potential candidates for EU membership (such as the various states of the Balka$\mathrm{ns})$; procurement provisions are included in agreements with states covered by the European Neighborhood Partnership framework in North Africa, the Middle East and the former Soviet Union; and trade agreements with Mexico (2000), Chile (2002), Columbia and Peru (2013), Ecuador (initiated in 2014) also contain extensive provisions for mutual access to procurement markets based on various pre-existing award-procedure models such as those of NFATA and the WTO's Agreement on Government Procurement (GPA). For many of the EU's major trading partners - e.g. the US, Japan and Canada - mutual access to procurement is provided under the framework of the GPA itself, as explained further below. However, the EU also has additional bespoke agreements with some of these countries allowing the access to procurement beyond that provided under the GPA framework. Figure 2 summarises some of the trade agreements that go beyond the EU's general commitments under WTO rules.

Given this policy, from the EU's point of view any acceptable agreement with the UK would need to include extensive procurement provisions. But what might those provisions be?

In terms, first, of coverage - types of entities and contracts covered - we can note that the scope of coverage under the EU's existing bespoke agreements seems to be largely constrained by the willingness of trading partners to open up their own markets based on reciprocity. To the extent that partners have been willing to open up procurement of a type covered by the EU's own internal rules, the EU itself has been willing to reciprocate; and the trade agreements have been modeled on those of the EU directives as far as possible. This reflects the fact that technically it is 


\section{Bespoke option for the UK procurement practices}

\section{Bespoke Trade Agreements: \\ - General A greement on Tariffs and Trade (GATT) \\ - Trade agreements with Mexico (2000), Chile (2002), Columbia and Peru (2013), Ecuador (initiated in 2014) \\ - Agreement on Government Procurement (GPA)}

Figure 2

Bespoke trade agreements that go beyond the EU's general commitments under WTO rules.

Source: Author's Compilation.

easier to define coverage by reference to concepts already used in EU directives, as well as the EU's willingness formally to open to markets covered by its own directives. Thus in the case of Switzerland, in particular, not only is there significant mutual opening of public procurement markets under the GPA, but a separate agreement on procurement (concluded in 2002) follows the coverage pattern of the EU directives by extending mutual opening to include certain utilities sectors and entities (private utilities with special or exclusive rights) that are not covered within the GPA framework, but are covered by the EU directives.

It would be inconsistent with this general policy for the EU not to offer to the UK at least all markets covered by the directives in return for a reciprocal UK commitment. Further, the UK may indeed wish to reciprocate given that most UK markets are already open formally to non-EU, as well as EU, countries, under the GPA (see below) and are open de facto to all countries anyway (even though not all foreign suppliers have legal rights to enforce access). Whether the UK would be willing to open up procurement not covered by the GPA, notably low value procurement and utilities procurement of private entities with special or exclusive rights, could perhaps be debated, however, especially there may be political pressure to use low-value procurement to promote SMEs and a concern over bureaucratic award procedures for low value and private procurement.
In terms of the technical way in which covered procurement is defined - the use of the definition of contracting authorities and public contracts etc then certainly the familiar EU approach can be expected to be used. (It is worth noting that the UK has recently used these familiar "EU" concepts to define the scope of certain purely domestic procurement rules, such as in the Public Services (Social Value) Act 2012, Equality Act 2010 and Small Business, Enterprise and Employment Act 2015.) The UK may perhaps prefer not to follow all the EU rules defining covered transactions - for example, it might prefer a wider exemption than the EU rules allow for contracts between public bodies. However it would be difficult to negotiate such exemptions.

The bespoke trade agreements generally also provide for transparent award procedures to support marketing-opening commitments, often using an established system (e.g. the GPA) that is familiar to the partner that must apply it. For procurement to which the GPA award procedures will not necessarily apply (private utilities etc) the Agreement with Switzerland provides not for use of an established model, but for covered procurement to be awarded simply in accordance with principles of "non-discrimination, transparency and fairness", as well as providing for explicit obligations regarding advertising, time limits, award criteria and selection criteria/qualification systems and specifications - perhaps because specifying more detailed procedures would be unpalatable to the relevant private utilities. 
It seems a strong possibility that award procedures in an EU-UK agreement would be those of the existing EU rules, both for the EU itself (which would in any case have to apply such rules if there were a national treatment obligation) and for the UK. This seems a strong possibility both because it is simple for the UK to use the existing award procedures and because the EU may be unwilling to accept less stringent procedures (e.g. those of the GPA) than the EU uses itself: whilst lack of familiarity and input makes it unreasonable to impose the EU directives' procedures on other trading partners, leading the EU to accept broadly comparable ones, these arguments do not have the same force for the UK. However, the question would then arise, as with the EEA Agreement, of how to deal with future legislative changes and ECJ interpretations, and centralised enforcement (as carried out by the Commission in the EU) may also be an issue. Alternatively, the UK might obtain an agreement on similar terms to certain others states merely to apply other adequate award procedures, in which case the most obvious standards to apply would be those of the GPA.

To summarise a complex situation, there are thus a number of feasible possibilities for an EU-UK procurement deal, some key ones being EU coverage plus EU award procedures (no change); EU coverage plus GPA award procedures; GPA coverage and EU award procedures; or using the GPA framework for both coverage and award procedures ${ }^{16}$. The latter would, effectively, be the "GPA option" (Section V below).

Finally, any EU-UK procurement deal would also surely make provision on remedies, again perhaps based on existing EU remedies rules or possibly based on the GPA standards (which are similar, although less stringent and elaborated in some respects). Negotiating a bespoke arrangement would, of course, involve more complex negotiations than EEA membership since for many areas (such as tariffs) it would not involve off-the-shelf solutions - although we have suggested that such off-the-shelf solutions might be applied for the area of public procurement itself. However, a bespoke arrangement seems a very likely option.

16 K Stewart, 'What effect will Brexit have on the public procurement rules?' (2018) Brexit series.

17 A Brown, L Van den Hende, D Livingston and E White, 'What future for public procurement regulations in the UK post Brexit? (2017) Herbert Smith Freehills LLP.

\section{The GPA Option}

The Government Procurement Agreement (GPA) is a multilateral agreement to which the EU and many of its leading trading partners (such as USA, Canada, Japan, Israel, etc.) are party. The GPA gives its parties qualified access to each other's public procurement markets.

The UK is currently a party to the GPA by virtue of its membership of the EU. There is some uncertainty ${ }^{17}$ over whether, during the post-Brexit period, the UK will automatically convert to being a GPA party in its own name or whether it will have to formally "re-apply" for membership. Putting that legal complication to one side, the GPA model would be the obvious fall-back option for the future relationship between the UK and the EU in the field of public procurement, if no more detailed provisions are agreed in any EU-UK trade agreement.

The GPA provides an extensive set of rules and remedies for regulating procurement by public entities, which are broadly similar to those found in the EU procurement directives. However, the GPA rules are much less detailed on issues such as how to award concessions, the modification of existing contracts and the exemptions for procurement between public bodies. The GPA also has less extensive coverage than the EU directives and current UK Regulations: for example, the GPA does apply to private utilities or to the defense sector. The European Parliament therefore suggests that any EU-UK trade agreement could expand upon certain elements of the existing GPA rules, under a "GPA-plus" option. But what is the position of the WTO specifically for public procurement regarding the "GPA option"?

As we noted, this is governed by the Government Procurement Agreement (GPA) (mainly the version concluded in 2012). This is actually different from most WTO agreements in two important ways. First, unlike other WTO agreements, it is optional. However, the EU and its major trading partners, such as the USA, Japan and Canada, are all Parties. Secondly, what markets are opened up under the GPA depends on bilateral negotiations between the different Parties and a Party is not required to give the same commitments to all trading partners. In principle the EU (including the UK) currently opens up all procurement covered by the EU directives, although with exceptions - in particular, the GPA does not cover certain procurement covered by the Utilities Directive, including by 
private utilities, and there is more limited coverage of defense and concessions (and there is also no coverage of procurement below the EU directives' thresholds). But this broad coverage does not apply for all Parties - where other Parties do not reciprocate in a particular area (e.g. a specific utility sector), the EU limits access to equivalent procurement of its own.

For procurement that is covered, the GPA sets minimum standards for transparency in award procedures. These are similar in their essentials to those of the Utilities Directive (or more accurately, to those of the EU's early Utilities Directive, before it was burdened with the detail added in 2004 and 2014). However, where Parties have national award procedures going beyond these standards they must apply these national procedures for the benefit of other GPA countries too. Thus the EU must, for example, allow US and Japanese suppliers to enforce the directives' procedures where the GPA covers the contract in question. But what will happen under the GPA if the UK leaves the EU?

For procurement that is covered it appears that if it leaves the EU the UK will cease to be a Party to the GPA. This is because it is not currently a Party to the 2012 (or previous, 1994) GPA in its own right but only by virtue of EU membership. This means that the UK will need to apply separately to join the GPA and - like any other applicant - must negotiate with all the current GPA Parties (the EU included), both to decide which of its procurements will be covered and to convince the other Parties that it has procurement law compliant with the GPA rules. It is highly unlikely that the UK would not want to re-join as rapidly as possible; not to do so could mean losing access to important procurement markets of both current GPA Parties and those of the increasing number of countries that are interested in acceding (and here it is worth mentioning that China is currently negotiating to join the GPA). It could also mean losing the opportunity to influence the future direction of the GPA under the forthcoming review of the Agreement. In practice, there also seems to be no reason why the other GPA parties would want to reopen the existing detailed coverage arrangements with the UK, or vice versa. Thus UK accession may be relatively straightforward. It is of interest, now, to have a look at the impact of the British Prime Minister's speech in Florence, on the $22^{\text {nd }}$ September 2017.

Speaking in Florence on the $22^{\text {nd }}$ September 2017, British Prime Minister, Theresa May, seemed to re- ject both a "Norway-style" or "Canada-style" free trade agreement between the EU and the UK, post-Brexit. She emphasised that both of these models would be too restrictive, compared to the free trade that currently exists between the EU and the UK. Instead, the British Prime Minister called for a "creative solution" that takes account of the pre-existing regulatory relationship between the UK and the EU. This might mean that, in the field of public procurement, the UK ultimately looks for a deal which varies from the "EEA" or "GPA" models put forward in the European Parliament report and is even closer to the current position of unimpeded access to each party's public procurement markets (Figure 3).

The British Prime Minister also proposed that the UK's relationship with the EU be subject to a transitional "implementation period" of around two years, following the date of UK exit. During this period, the UK would continue to enjoy unfettered access to the single market and, in return, would remain fully subject to EU laws. It therefore appears that, during this two-year period (at least), lasting until March 2021, the UK would be obliged to retain the UK procurement regulations in their current form, fully implementing the terms of the EU directives on procurement and guaranteeing non-discrimination against suppliers from EU Member States. Likewise, the EU would be obliged to continue to afford UK suppliers non-discriminatory access to their own public procurement markets.

\section{The "Freedom Option"}

Despite the more conciliatory tone adopted by the British prime minister in her Florence speech, the clock is ticking and the time for reaching a UK-EU agreement on Brexit is steadily dwindling. What if no agreement is reached before the UK's formal exit on or around 31 March 2019?

In this "hard Brexit" scenario, the UK procurement regulations would remain in place, but would the UK Government introduce a rapid amendment to remove the duty of compliance that is currently owed to suppliers from the EU ? Such a change would seem unlikely if it is the case that the UK retains its membership of the GPA post-Brexit, since the GPA requires the UK not to discriminate against suppliers from other GPA states (including all of the EU states) when running procurement procedures falling with- 


\section{British Prime Minister's proposal (Florence, 22 Sept. 2017)}

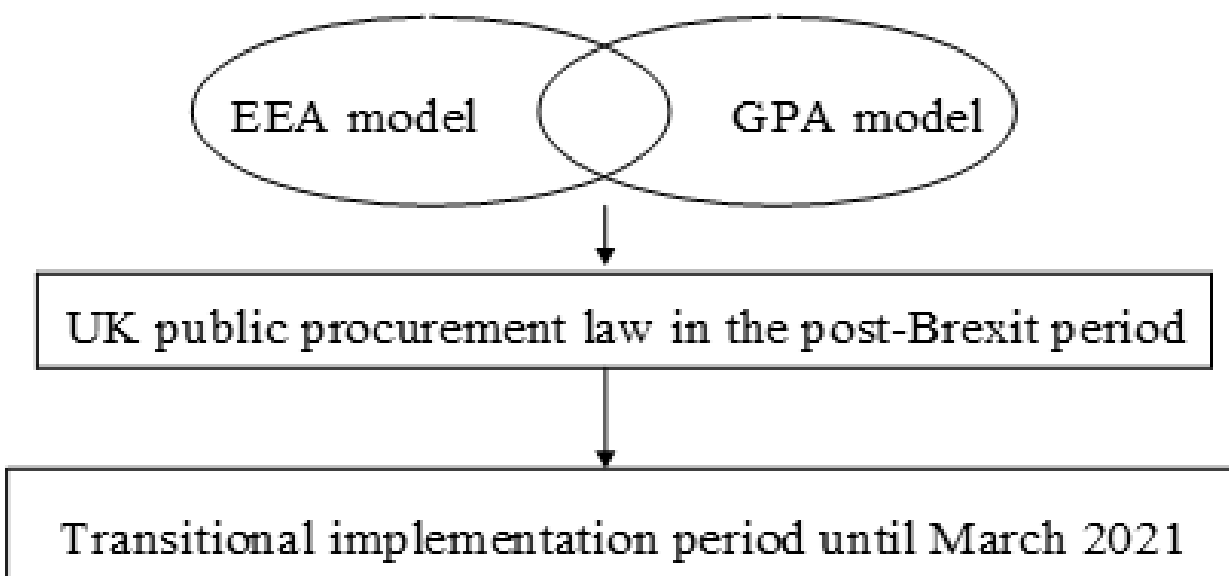

Figure 3

British Prime Minister's proposal for the future UK procurement law.

Source: Author's Compilation.

in the GPA's scope. Similarly, contracting authorities in the EU would also be bound by the GPA not to discriminate against UK suppliers in such procedures.

However, if the UK were not admitted as a party to the GPA on or following Brexit, all bets would be off. Contracting authorities in the EU (and in any other GPA territory) could choose to exclude or discriminate against UK suppliers in their public procurement procedures. This outcome might lead to the UK swiftly amending the UK procurement regulations so that they no longer guarantee rights or remedies to tenderers from EU or GPA states, save where these are provided for in any bilateral trade deal with any of those countries. On the other hand, if the UK continues to seek GPA membership, it would probably refrain from taking this step.

Any UK suppliers which regularly tender crossborder for public contracts in the EU States, along with any EU suppliers which tender cross-border for UK public contracts, will have the most to lose from any failure of the UK and EU to reach an agreement regarding their trading relationship post-Brexit. In that scenario, unless the GPA comes to the rescue, those suppliers could be left high-and-dry, with no rights of access to fair treatment in public procurement procedures in those markets. These suppliers will be watching anxiously to see whether Messrs Davis and Barnier can finally get their act together in the ongoing negotiations. Therefore, at this stage it is worth commenting, in more detail, on what kind of procurement law the "freedom option" might produce. It is in fact very difficult to speculate but a few points can be made.

A first point is that while the aim of EU procurement law is to open up markets, this EU law and the implementing UK regulations de facto also provide a system of transparent procurement procedures of the kind that countries often put in place to support value for money and anti-corruption objectives in procurement. A key question is whether without the constraints of EU law (or the similar GPA) the UK would altogether reject the use of law as a tool to achieve its procurement goals and revert to the old system of "administrative" regulation by guidance. This is a possibility. However, it is notable that the UK jurisdictions have recently come to use law more and more even in relation to purely "domestic" procurement policies, examples being the regulation of below-EU thresholds procurement in the Public Contracts Regulations 2015 (implementing the "Lord Young" reforms) in England and Wales and via the Procurement Reform (Scotland) Act 2014 and conse- 
quent procurement Reform (Scotland) Act 2016 Regulations; and the general power to make procurement regulations under the Small Business, Enterprise and Employment Act 2015 and the Public Services (Social value) Act 2012. This suggests broad acceptance of the legal regulatory approach, possibly because of the influence of EU law. Further, before the procurement regulations were adopted the court had already begun to develop tools to regulate public procurement, notably the "implied contract" governing the tendering process recognised in the Blackpool case. These judicial tools have taken a back seat with the courts generally declining to apply them to situations governed by the procurement legislation. However, they could be resurrected and expanded; especially now the courts have experience of procurement law, and legislation may be seen as preferable to piecemeal judicial development.

A second point to make is that the absence of external constraints could provide the opportunity to improve the procurement rules ${ }^{18}$. In the author's view this would entail, as mentioned, a single system for all procuring entities and a system that is both simpler and more flexible. A further improvement would be to introduce a system of remedies that is available only when there is significant fault by a procuring entity, but which - as a quid pro quo - is also cheaper and easier to use, so providing a better balance between costs and benefits of a legal remedies system.

However, the actual content of any new domestic system of procurement, and the extent to which it might be an improvement on the current system, is impossible to predict. Rather than producing a more streamlined approach it is equally possible that a blank canvas could result in complex patchwork of provisions and additional bureaucracy, which some might say is a feature of the current "domestic" provisions.

It is also worth noting that more national freedom is likely to produce greater divergence between the rules applying in the different UK jurisdictions. This is because under the devolution settlement of 1998 public procurement became an area of responsibility for the devolved governments in Scotland, Wales and Northern Ireland. Free from EU constraints, including the identical implementation of EU rules for England, Wales and Northern Ireland, these jurisdictions are likely to go in different directions, especially in view of the strong political pressure outside Eng- land to use procurement as a tool to promote local industry and social policies.

In addition to the above, it is worth mentioning that, whatever the content of any domestic rules, it seems plausible that the domestic regime might continue to be shaped by EU-inspired concepts where these are uncontroversial and familiar - for example, that the entities covered by domestic legislation might still be defined by reference to the concept of a "contracting authority".

\section{The Transition Period}

The European Court has taken a central role in shaping the development and interpretation of EU (and hence UK) procurement law over the last 25 years. The Court's rulings have established key principles on numerous issues, including the scope for cooperation between public entities, modifications to existing public contracts, the rights of bidders to rely on the capacities of third parties and the need for a standstill period prior to contract signature with the successful bidder.

The EU Withdrawal Bill currently before Parliament will curtail the supremacy of the European Court of Justice, post-Brexit. The Bill provides that, following the date of UK exit from the EU, British courts and tribunals will not be bound by any decisions or principles which are laid down by the European Court after exit day. Thus, after exit day, any question as to the validity, meaning or effect of EU law which is retained on the UK statute book will have to be interpreted by first instance courts in accordance with any retained EU case law or principles. Conversely, the Bill states that the Supreme Court, and the High Court when sitting as a court of appeal, will not be bound by any retained EU case law. However, when deciding whether to depart from any retained EU case law, these Courts will have to apply the same test as they would apply when deciding to depart from their own case law, so their hands are still tied to some extent.

Following Prime Minister May's proposal for a two-year "implementation period" after March 2019, it appears that the above changes would not come in-

18 V Moorcroft, 'Brexit: the end of public procurement rules or business as usual?' (2017) Brexit series. 
to effect until March 2021 (at the earliest). After the transitional implementation period expires in March 2021, it follows from the EU Withdrawal Act that the English courts will no longer be obliged to apply any new principles or findings laid down by the European Court. Nonetheless, given that the UK procurement regulations are currently based closely on the provisions of the EU procurement directives and are likely to remain so for the foreseeable future, it seems likely that in practice UK judges will still take into account any pre- or post-Brexit rulings of the European Court which interpret those rules.

In her Florence speech, Theresa May accepted that, post-Brexit, UK courts should be able to take into account ECJ judgments when interpreting UK law on citizens' rights, whenever there is any uncertainty regarding underlying EU law. It would make sense for the UK courts to take a similar approach, post-Brexit, towards the interpretation of the UK procurement regulations, given that they are based almost entirely on EU law. Some analysts ${ }^{19}$ believe that government policy as outlined in the Prime Minister's Florence speech, is to seek a period of transition before any new "deep and special" partnership agreement is negotiated between the UK and the remainder of the EU. The European Council agreed to enter negotiations for a transition period at its meeting in December and expectations are that such a period will last about two years.

There is uncertainty about how a transitional agreement might be implemented in domestic law. The most straightforward way of achieving a transition period is to extend the Article 50 period for withdrawal and defer exit day beyond 29 March 2019. There is now power in the Withdrawal Bill to do so, however the political difficulty of doing so seems to rule out this option.

Other options such as including a transition period in the withdrawal agreement will test the elasticity of the word "withdrawal" when the ambition of the transitional agreement is to achieve a situation as close as possible to the present but without UK membership of the EU. Is that really "withdrawal"? Moreover the Withdrawal Bill ends the jurisdiction of the Union Courts in the UK on exit day and repeals the European Communities Act thereby depriv-

19 R Breedon and S Sellers, 'The long and winding road: public procurement after Brexit' (2018) Gowling WLG. ing the Government of the means for implementing new EU directives and regulations during this period. As for public procurement law, a transitional agreement seems certain to postpone any scope for delivering the kind of change which the LGA has in mind for at least another two years.

It is finally important to consider what the position might be in the short term if negotiations with the EU and (possibly as a consequence of this) negotiations for GPA accession and other trade agreements are not completed at the time of Brexit. This would in fact mean the UK trading with the EU based solely on the EU's commitments under the WTO Agreements. However, as we have seen, this would not include any mutual commitments on procurement, including between the UK and EU or UK and other GPA Parties, since cessation of EU membership would also mean cessation of GPA membership. In this scenario there would at the time of Brexit be no trade commitments on public procurement to constrain domestic procurement policy.

It is not clear what would happen to the current procurement regulations pending completion of the negotiations. It is hard to see that these would be retained/renewed exactly as they are, since this would give EU suppliers access to UK procurement for this interim period without reciprocal commitments to UK suppliers (although this would not be the case with suppliers from other GPA countries, whose access under the regulations is specifically dependent on reciprocal access being given under the GPA or other comparable agreements). However, it hardly seems satisfactory to repeal the regulations for what might be a fairly short time.

A sensible and likely interim solution would, therefore, be to retain the award procedures of the regulations in place, but without provision for enforcement by non-domestic suppliers, pending eventual confirmation, modification/replacement, or total repeal of the regulations, depending on the outcome of trade negotiations and other decisions on how procurement will be regulated after Brexit.

\section{Conclusions}

All that can be said with reasonable certainty on the future of the UK public procurement regulations is that they will remain as they are now for at least two years after the UK applies to leave the EU, and for 
longer if the period for negotiating Brexit is extended. In the longer term, the position in terms of the legal constraints on public and utility purchasers will depend mainly on the content of any trade agreements that are negotiated with the EU.

The extent to which Brexit will affect the public procurement rules in the long term remains unknown, and will ultimately depend on the UK's continuing relationship with the EU. Once the UK is outside of the EU, it may have greater flexibility when it comes to implementing and amending public procurement legislation. Parliament may, for instance, take steps to reduce the scope for any potential challenges to public sector organisations under public procurement legislation.

It is unlikely that the Public Contracts Regulations 2015, which encompass the EU procurement directives, will see any immediate alterations. In addition, the principles of equal treatment, transparency and non-discrimination are key principles of public trade and procurement and are enshrined in UK law. A departure from the EU, however dramatic, will not seek to amend these principles, though may raise questions regarding how the principles are to be interpreted.

There are many areas of procurement law, though, where the regulations are open to a considerable degree of interpretation. In interpreting these regulations, UK courts must currently look to the jurisdiction of other courts in Europe. However, on leaving the EU, the UK courts may be more willing to diverge from the decisions of courts in Europe and adopt a more flexible approach.

Along with case law, the recitals to the procurement directives are used to interpret public procurement law and in some instances include important additional information. These directives will not be included in the European Union (Repeal) Bill and therefore may not apply following the UK's withdrawal from the EU.

Questions have arisen as to the role of the Official Journal of the European Union following the UK's withdrawal from the EU. If UK contracting authorities are no longer able to publish OJEU notices, questions need to be answered regarding how contracting authorities remain compliant with the procurement regulations and where contract opportunities will need to be published.
Commentators have suggested that the UK's withdrawal from the EU may lead to the UK adopting changes to procurement legislation with the aim of increasing flexibility in areas such as the modification of contracts, which are currently rigidly governed. In the future, it could be easier for contracting authorities to make changes to contracts without embarking on a new procurement exercise.

In the long-term, the impact of the Brexit decision on public procurement regulation in the UK will depend on the UK's relationship with Europe. Continued access to the single market, for instance, is likely to require full application of EU procurement regulation. It is also expected that membership of the EEA would require compliance with EU procurement law.

Clearly resolution of the trade issues will not be easy and there is a serious possibility that this will not happen by the time of Brexit, meaning that there will be a period during which no trade agreements apply to procurement at all. What will happen to the current UK procurement regulations during any period of post-Brexit negotiations is not clear. However, it is quite likely that these regulations will be retained in effect so far as the award procedures are concerned, although possibly enforceable only by national suppliers, to avoid giving market access to other countries without reciprocal arrangements

In addition, if outside the single market, it is anticipated that the UK will remain party to the Agreement on Government Procurement (GPA), a World Trade Organization (WTO) agreement, which would limit the extent to which the UK can rewrite the rule book on public procurement. The UK currently participates in the GPA by virtue of its membership of the EU; however, the Trade Bill makes provision for the UK to become an independent signatory to the Agreement. Many of the rules under this Agreement correspond with the rules under the EU procurement directives and accordingly the scope for amendment to UK procurement law is expected to be limited.

Finally, even if public procurement legislation is amended considerably in order to increase flexibility, academy trusts should note that the Academies Financial Handbook requires academy trusts to ascertain value for money. This requirement is most clearly met by some form of competitive tender process and benchmarking exercise. 